\title{
Use of the traditional halibut hook of the Makah Tribe, the čibu-d, reduces bycatch in recreational halibut fisheries
}

\author{
Joseph R Petersen ${ }^{1,2}$, Jonathan J Scordino ${ }^{\text {Corresp., } 1}{ }^{\text {, Cole I Svec }}{ }^{1}$, Reginald H Buttram ${ }^{1}$, Maria R Gonzalez ${ }^{1}$, Joe \\ Scordino $^{3}$ \\ 1 Makah Fisheries Management, Makah Tribe, Neah Bay, Washington, United States of America \\ 2 Northwest Indian Fish Commission, Forks, Washington, United States of America \\ 3 Scordino Consulting, Edmonds, Washington, United States of America \\ Corresponding Author: Jonathan J Scordino \\ Email address: jonathan.scordino@makah.com
}

A previous study found that use of the traditional halibut hook (čibu.d) of the Makah Tribe in present day recreational Pacific halibut (Hippoglossus stenolepis) fisheries significantly reduced bycatch compared to paired $8 / 0$ circle hooks. The study also found that the čibu'd had a significantly reduced catch of halibut, but that the reduction may have been due to manufacturing flaws in the čibu.d used in the study. In this two-phased study, we first compared the fishing performance of redesigned čibu $d \mathrm{~d}$ made from four different materials: brass, stainless steel, plastic, and wood. In the second phase, we compared the fishing performance of the brass čibu $d$ with two common recreational fishing set-ups: a single large 16/0 circle hook and paired 8/0 circle hooks. The fishing performance of the redesigned čibu.d was not statistically different for čibu.d made of brass, stainless steel, or plastic. However, the čibu $d$ made from wood had significantly lower catch of halibut than the other čibu.d. We selected the brass čibu.d for the second phase of the study for continuity with the previous study of čibu $d$ and found that it had significantly less bycatch and a lower bycatch ratio than both the paired $8 / 0$ and single $16 / 0$ circle hooks. No significant differences were found in catch rates of halibut for paired $8 / 0$ circle hooks, 16/0 circle hook, and the brass čibu.d. This study demonstrates that the improved catching performance of čibu.d on halibut and reduced bycatch compared to other popular approaches can be achieved by using brass čibu.d. Managers of recreational halibut fisheries should consider the use of čibu $d$ in areas where bycatch is a concern. 
1 Use of the traditional halibut hook of the Makah Tribe, the čibu-d, reduces bycatch in 2 recreational halibut fisheries

4 Joseph R. Petersen ${ }^{1,2}$, Jonathan J. Scordino ${ }^{1}$, Cole I. Svec ${ }^{1}$, Reginald H. Buttram ${ }^{1}$, Maria R.

5 Gonzalez $^{1}$, and Joe Scordino ${ }^{3}$

6

7 1 - Makah Fisheries Management, Makah Tribe, Neah Bay, Washington, USA

82 - Current Address: Northwest Indian Fish Commission, Forks, Washington, USA

93 - Scordino Consulting, Edmonds, Washington, USA

10

11 Corresponding Author:

12 Jonathan Scordino

13 PO Box 115, Neah Bay, Washington, 98357 USA

14 Email Address: jonathan.scordino@makah.com 
16

17

18

19

20

21

22

23

24

25

26

27

28

29

30

31

32

33

34

35

36

37

38

39

40

41

42

43

44

45

46

47

48

49

50

51

52

53

54

55

\section{Abstract}

A previous study found that use of the traditional halibut hook (čibu $\cdot d$ ) of the Makah Tribe in present day recreational Pacific halibut (Hippoglossus stenolepis) fisheries significantly reduced bycatch compared to contemporary paired $8 / 0$ circle hooks. The study also found that the čibu $d$ had a significantly reduced catch of halibut, but that the reduction may have been due to manufacturing flaws in the brass čibu $d$ used in the study or due to our choice to use brass to make the čibu $\cdot d$. In phase 1 of this two-phase study, we compared the fishing performance of redesigned čibu $d \mathrm{~d}$ made from four different materials: brass, stainless steel, plastic, and wood. The brass, stainless steel, and plastic čibu $d \mathrm{~d}$ had statistically similar fishing performance. We selected the use of the brass čibu $\cdot d$ for comparing to contemporarily fished circle hooks in recreational halibut fishing for continuity with our previous research for phase 2 of this study. Phase 2 of the study found no significant differences in catch rates of halibut for paired $8 / 0$ circle hooks, $16 / 0$ circle hook, and the redesigned brass čibu $\cdot d$. The brass čibu $\cdot d$ had significantly less bycatch and a lower bycatch ratio than the paired $8 / 0$ circle hooks and the $16 / 0$ circle hook. Although not the objective of this study, we also found the $16 / 0$ circle hook had lower bycatch than the paired $8 / 0$ circle hooks. This study demonstrates that improved catching performance of čibu $\cdot d$ on halibut and reduced bycatch can be achieved by using the redesigned brass čibu $d$. Managers of recreational halibut fisheries should consider requiring the use of čibu $d \mathrm{~d}$ or the larger 16/0 circle hook in areas where bycatch is a concern.

\section{Introduction}

The ecological impacts of recreational fishing have commonly been overlooked in favor of focusing on the impacts of commercial fisheries, but the effects of recreational fisheries can be significant to both the target species and bycatch (McPhee, Leadbitter \& Skilleter, 2002; Coleman et al., 2004). Recreational fisheries can have higher impacts than commercial fisheries in localized areas (Cooke \& Cowx, 2004). The effects of bycatch in recreational fisheries for Pacific halibut (Hippoglossus stenolepis; hereafter halibut) are poorly known due to lack of observer coverage and unknown amounts of bycatch discarded at sea (Cooke \& Cowx, 2004; Lewison et al., 2004). Recreational halibut fisheries are monitored through port samplers checking retained catch and having anglers self-report their bycatch. Self-reporting may be accurate (Figus \& Criddle, 2019) but it is very difficult to verify, making it difficult to evaluate just how much bycatch occurs in recreational halibut fishing. Bycatch released at sea is vulnerable to a variety of stressors, including risk of infection from hooking injuries, loss of predator avoidance, barotrauma, and other stress induced by time on deck, all of which can directly impact the ability of a bycaught fish to survive (Trumble, 1996). Recently, state management agencies have required the use of descending devices because recompressed rockfish have an improved probability of post-release survival (Hannah, Parker \& Matteson, 2008; Hannah, Rankin \& Blume, 2014; Bellquist et al., 2019). However, recent studies have 
56 found that rockfish may experience prolonged effects from barotrauma that can negatively affect 57 their survival (Rankin et al., 2017). Thus some species bycaught in recreational halibut fisheries, 58 because of their physiology (like rockfish) or because of their life history (like spiny dogfish) (Stevens et al., 2000), are vulnerable to overfishing even at modest levels of incidental mortality during fisheries. Improving the selectivity of fishing gear used in recreational halibut fisheries would make them more sustainable and minimize their impacts on non-target species.

62

The traditional halibut hooks used by Native Americans of the Pacific Northwest were designed and refined over thousands of years of trial and error to target halibut while minimizing catch of non-halibut species (Stewart, 1977). Prior to contact with Europeans, the halibut hooks were made from wood and had a bone barb and after contact metals were utilized in the construction of čibu $d$ first in making the barb and later in making the entire hook. Note that in this paper we use the term 'barb' to refer to the bone or steel that is added to the čibu $d$ frame that stabs through a fish's mouth to be consistent with past descriptions of traditional hooks (Swan, 1870; Stewart, 1977; Malindine, 2017; Salmen-Hartley, 2018). In a previous study, we evaluated if using the Makah Tribe's traditional halibut hook (known as the čibu·d, Fig. 1) could reduce impacts of bycatch during recreational halibut fishing (Scordino et al., 2017). Our study confirmed that the čibu $\cdot d$ is more selective for recreationally catching halibut than modern hook configurations. However, the study also found that the čibu'd significantly reduced the catch of halibut when compared to commonly used paired $8 / 0$ circle hooks (Scordino et al., 2017).

We identified two characteristics of the čibu $d$ fished in our previous study that affected its fishing performance (Scordino et al., 2017). Our previous study used handmade hooks that were variable in size and the position of the barb in the hook; we found that čibu $\cdot d$ that caught the most halibut had a mean distance of $36 \mathrm{~mm}$ in length from the tip of the barb to the bottom of the čibu $\cdot d$ frame (Fig. 1). This was a significantly larger gap than čibu $d$ that did not catch halibut (mean distance of $32 \mathrm{~mm}$ ). Second, the straightened fish hook used for the barb of the čibu $d$ may also have been too weak, suggesting that a stronger barb would improve fishing performance (Scordino et al., 2017).

Although not evaluated in the previous study, the material used to manufacture the čibu $d$ may have also affected fishing performance. In 1880, fishermen of the Makah Tribe landed 719.5 metric tons of halibut while hand lining čibu $\cdot d$ (Collins, 1996). Traditionally, the čibu $\cdot d$ was made from steam bending a single piece of hemlock, true fir, or yew and affixing a barb made from bone or antler (Stewart, 1977). It is likely that many or most of the čibu $\cdot d$ used in 1880 were made of wood. The positive buoyancy of a wooden čibu $\cdot d$ may have made it more effective for catching halibut as compared to brass čibu $\cdot d$ that are negatively buoyant. This observation lead us to hypothesize that fishing performance of the čibu·d tested in Scordino et al. (2017) may 95 
96 Our previous study (Scordino et al., 2017) showed that the čibu $\cdot d$ was a promising tool for 97 managers to use in recreational halibut fisheries with bycatch concerns. However, the significant 98 reduction in observed halibut catch rates with the čibu $d$ likely would frustrate anglers who often 99 assess fishing satisfaction based on catching their target fish (Arlinghaus, 2006). The objective of 100 this study was to determine if the performance of the čibu $\cdot d$ for catching halibut could be 101 improved through modifications of the čibu $\cdot d$ construction while maintaining the beneficial 102 reductions in bycatch observed in our previous study (Scordino et al., 2017). To achieve this

103 objective, we conducted a two-phase study. In phase 1, we evaluated if the material used to 104 construct čibu $\cdot d$ affects their fishing performance by comparing catch rates on čibu $d \mathrm{~d}$ made of 105 brass, stainless steel, plastic, and wood. In phase 2 of the study, we compared the best 106 performing čibu $\cdot d$ design from phase 1 of the study to two popular recreational halibut fishing 107 approaches used today: fishing with paired 8/0 circle hooks and fishing with a single 16/0 circle 108 hook. We evaluated fishing performance by comparing catch rates of halibut, bycatch rates, and 109 bycatch ratios between the three methods.

\section{Materials \& Methods}

112

\section{Manufacture of čibu·d}

114 Our study design required the manufacture of čibu $d$ from plastic, wood, stainless steel, and

115 brass (Fig. 2). Each of the four material types required different manufacture protocols as

116 described below. All improved čibu $d$ for this study were made with as similar a shape as

117 possible to minimize the possibility that hook shape affected fishing performance. A

118 documentary video on this project with a detailed demonstration of how the wooden čibu $\cdot d$ and

119 brass čibu $d$ were handmade and how metal čibu $\cdot d$ were made on a compact metal bender is

120 available at the Makah Museum in Neah Bay, WA.

121

122

The design of the metal čibu $\cdot d$ used in this study were improved based on observations from our previous research (Scordino et al., 2017) in four ways (Fig. 1): 1) we used 0.3175 diameter stainless steel rod for the barbs of the čibu·d instead of straightened fish hooks; 2) we welded or silver soldered the barb to the frame of stainless steel and brass čibu $\cdot d$, respectively, rather than securing the barb by wrapping in wire and soldering with plumbing solder; 3) we standardized the shape of the čibu $\cdot d$ frame and position of the barb inside the frame with the barb tip positioned $36 \mathrm{~mm}$ above the bottom of the frame; and 4) we drilled a hole through the top of the čibu $d$ frame to secure a leader rather than securing a large barrel swivel directly to the čibu $\cdot d$ frame. The revised attachment of the leader made the improved čibu $\cdot d$ smoother on the inside of the frame than the previously tested čibu $\cdot d$.

132

The frames of the brass and the stainless steel čibu $d$ were made from rods of 360 half-hard

134 tempered brass and 316 stainless steel with a diameter of $0.635 \mathrm{~cm}$ and a length of $30.5 \mathrm{~cm}$. We 135 used a bench grinder and tapered the rod down to a $1 \mathrm{~mm}$ diameter tip on one side of the rod 
136 starting three $\mathrm{cm}$ from the end. We achieved a consistent taper by making a tool for the bench

137 grinder to guide the angle at which the rods were tapered. For quality control, we compared each

138 tapered rod to a reference rod with an ideal taper and discarded any that were incorrectly tapered.

139 We developed a stepwise procedure to shape the metal čibu $\cdot d$ frames with high precision and

140 consistency using a compact metal bender. All čibu $\cdot d$ frames were shaped by author RB to

141 further ensure consistency of shape. The barbs for both the brass čibu $d$ and the stainless steel

142 čibu $d$ were made out of $0.3175 \mathrm{~cm}$ diameter 316 stainless steel rod that was cut to $5 \mathrm{~cm}$ and

143 tapered into a sharp point. The barb was welded onto the stainless steel čibu $\cdot d$ frame and silver

144 soldered onto the brass čibu $d$ frame with the barb tip positioned $36 \mathrm{~mm}$ above the bottom of the

145 frame. We wrapped the bottom of the frame with cotton twine to add texture to hold the bait in

146 position. At the balancing point of the top of the čibu $\cdot d$ frame on both the brass and stainless

147 steel čibu $\cdot d$ a $2 \mathrm{~mm}$ hole was drilled horizontally for the attachment of a fishing wire leader and

148 barrel swivel.

149

150 The wooden čibu $\cdot d$ were made with traditional materials used by the Makah Tribe as generally

151 described by Stewart (1977). Materials collected to construct the wooden čibu $d$ were western

152 hemlock (Tsuga heterophylla) branches, Sitka spruce (Picea sitchensis) root, tallow, and elk

153 femur. Sections of western hemlock branches with a diameter of about $4 \mathrm{~cm}$ and length of 30.5

$154 \mathrm{~cm}$ were radially cut into sixths to make blanks for shaping into čibu $d$. The blanks were shaved

155 to achieve a triangular shaped cross-section by removing wood on the pith side and preserving

156 the continuous grain along the bark side to maintain the strength of the finished čibu $\cdot d$. The

157 blank was tapered to a narrow tip starting $3 \mathrm{~cm}$ from one end of the blank. The completed

158 hemlock blank was steamed until pliable and bent and secured around a form with the tapered

159 end oriented on the top of the čibu $d$ frame and the pith side of the blank was aligned towards the

160 inside of the form. Once affixed to the form, we cured the blank at room temperature for 24

161 hours. After curing, the blank was notched with a slot to attach the barb. We then heated the

162 frame and applied tallow to the entire blank to seal the wood against moisture and help it hold

163 shape (Stewart, 1977). A sharpened piece of worked elk femur of roughly $10 \mathrm{~cm}$ was affixed in

164 the notch using thin strips of spruce root so that the tip of the barb was roughly $36 \mathrm{~mm}$ from the

165 bottom of the frame of the čibu $d$. The spruce root wrap secured the barb and also provided

166 texture to hold the bait in position by continuing wrapping the frame from the barb insertion

167 point to a position directly below where the where the leader was secured to the top of the čibu $\cdot d$

168 frame. The tip of the čibu $d$ frame opposite where the barb was attached (top of frame) was also

169 wrapped in spruce root to mimic how the Makah traditionally made the hook (Fig. 2). All of the

170 wooden čibu $\cdot d$ were handmade and although we attempted to standardize the shape and position

171 of the barb in each, there was variability in the completed čibu $d$.

172

173 We contracted Benchmark Molding of Edmonds, Washington to make the plastic čibu·d.

174 Benchmark Molding created a design similar in shape to the metal čibu $d$ used in this study. The

175 shape of the plastic čibu·d was different in two ways. First, two bumps were added near the 
176 balancing point of the hook on the top of the frame for tying a leader in place. Second, the

177 bottom of the čibu $\cdot d$ was designed with ribs wrapping around the čibu $d$ to help hold the bait in

178 place, thus negating the need to wrap the čibu $\cdot d$ in cotton twine. Like the metal čibu $\cdot d$, we used a

$1795 \mathrm{~cm}$ rod of $0.3175 \mathrm{~cm}$ diameter 316 stainless steel rod that was tapered to a sharp point. The

180 barb was securely held in place by being encapsulated within the plastic of the čibu $\cdot d$ frame and

181 held with the barb tip positioned with a gap from the point of the barb to the bottom of the frame

182 of the čibu d of $36 \mathrm{~mm}$. A $33 \%$ glass filled black nylon was injected to make the semi-rigid

183 frame of the čibu $\cdot d$. Tag ends from the injection process were trimmed to leave the final shape of

184 the čibu.d.

185

186 Field deployment

187 We conducted our field tests using nearly identical methods to our previous study (Scordino et

188 al., 2017). We contracted Windsong Charters for both phases of the study to provide the vessel

189 and volunteers. During both phases, fishing took place off the coast of northern Washington,

190 with all sites accessible from the port of Neah Bay (Fig. 3). The test hooks were fished off a 50.8

$191 \times 20.3 \mathrm{~cm}$ ' $L$ ' shaped spreader bar commonly used in recreational fishing that had a 0.9-kilogram

192 weight attached to the short side and the hook attached to the long side. We baited all hooks with

193 brined, blue label herring $(18-20 \mathrm{~cm})$ to avoid bait size causing a bias in our study (Kaimmer,

194 2004).

195

196 The sampling unit for each phase of the study was a 30-minute set. Prior to each set, the poles

197 were set up with the hook type alternating down the rail of the boat; two of the same hook type

198 were never fishing next to one another at the start of a set. We instructed anglers to actively fish

199 through the entire set and to catch as many fish as possible. When anglers caught fish, we

200 recorded species, length, and the hook type that caught the fish. When anglers hooked a fish, or

201 reeled up to check bait, we quickly rebaited their hooks to fish as continuously as possible during

202 a set. At the conclusion of each set, we rotated anglers counterclockwise to a new position on the

203 boat and a new hook type. Rotating the anglers to new positions on the boat reduced the potential

204 for bias caused by fishing location on the vessel and ensured that anglers fished all hook types.

205 The rotation of anglers also eliminated the possibility angler skill affecting catch rate. Our goal

206 was to compete at least six sets per sampling day but the actual number of sets per day was

207 variable due to factors including weather, distance from port to sampling locations, and energy of

208 the volunteers to continue fishing with consistent effort.

209

210 Our study design was very similar for both phases of the study except for a few notable

211 differences. First, in phase 1 we fished two replicates of each of four čibu $\cdot d$ types (brass,

212 stainless steel, plastic and wood) with eight anglers whereas in phase 2 we fished three replicates

213 of three hook arrangements (brass čibu $d$, paired 8/0 circle hooks, and 16/0 circle hook) with

214 nine anglers. Second, our deployment of hooks from the spreader bar was different during the

215 two phases of study. During phase 1, we attached the čibu $\cdot d$ to the spreader bar using leaders of 
2166 to $10 \mathrm{~cm}$ in length for all of the čibu $\cdot d$. During phase 2, the spreader bar was attached to either 217 a brass čibu $\cdot d$ with a 6 to $10 \mathrm{~cm}$ leader, a single $16 / 0$ circle hook with an 8 to $12 \mathrm{~cm}$ leader, or 218 paired 8/0 circle hooks with 12 to $16 \mathrm{~cm}$ leader to the top hook and gap between the top and 219 bottom hook of around $6 \mathrm{~cm}$. The leaders between hook types slightly differed in length in order

220

221

222

223

224

225

226

227

228

229

230

231

232

233

234

235

236

237

238

239

240

241

242

243

244

245

246

247

248

249

250

251

252

253

254

255 to minimize tangling during deployment. At the conclusion of each day of fishing during phase 1 we had anglers rank their preference for the čibu $\cdot d$ by material type from most to least preferred.

During phase 1 of this study, 75 experimental sets were conducted during 13 days of effort in June (29-30) and July (5-7, 12-14, 17-19, and 27-28) of 2017 in the Pacific Ocean and Strait of Juan de Fuca in the waters surrounding northwest Washington (Fig. 3). Sets ranged in depth from 85 to 207 meters with an average set depth of 149 meters. A bottom discrimination function on a Standard Horizon sonar was used to record substrate type. Fifty-eight of the sets were conducted over sand or gravel bottom substrate and an additional 17 sets were conducted in substrate mixed with rock or primarily rocky bottom. Phase 2 was conducted over 36 experimental sets over 5 days of fishing from June $20-28,2019$ at some of the same sites used in Phase 1 and also additional sites where bycatch rates are generally higher. Twenty-four of the sets were conducted in rock/gravel substrate and 12 were sand/gravel substrate.

The International Pacific Halibut Commission provided permits for the research activities performed in 2017 (permit \# EL2017070) and 2018 (permit \# EL2018045). For all species other than halibut, impacts from this research were recorded against the treaty set-asides within section 50 CFR 660.50 .

\section{Data analysis}

An ANOVA was used to analyze catch rates by hook type for halibut, bycatch species in aggregate, and for each species of fish caught for each phase of this study. We used a Tukey Honestly Significantly Different (HSD) test to determine what pair-wise comparisons of hook types caused the observed significant differences in ANOVA tests.

The bycatch ratio by hook type was evaluated with all catch data pooled during phase 2 of the study. A X ${ }^{2}$ test of independence was used to compare the ratio of halibut caught to bycatch. We conducted post hoc pairwise comparisons of bycatch ratios using a Bonferroni correction for multiple comparisons.

To evaluate if our modifications to the čibu $d$ outlined above improved the fishing performance of the čibu'd, we compared our results to our previous study (Scordino et al., 2017). We fished paired $8 / 0$ hooks as a reference for evaluating the fishing performance of čibu $\cdot d$ both during phase 2 of this study and in our previous study. To test if our design improvements to the čibu $d$ improved fishing performance for catching halibut we compared the ratio of halibut caught on čibu $d$ to halibut caught on paired 8/0 circle hooks in our previous study (Scordino et al., 2017) 
256 to results from phase 2 of this study with a Fisher's Exact Test. We also tested if the improved

$257 \mathrm{cribu} \cdot \mathrm{d}$ maintained its beneficial reductions of bycatch relative to paired $8 / 0$ circle hooks by

258 comparing the ratio of bycatch caught on the čibu $d$ and the paired $8 / 0$ hooks for our previous

259 study (Scordino et al., 2017) to results from phase 2 of this study using the improved čibu $\cdot d$.

260

261

262

263

264

265

266

267

268

269

270

271

272

273

274

275

276

277

278

279

280

281

282

283

284

285

286

287

288

289

290

291

292

293

294

\section{Results}

\section{Phase 1}

A total of 286 halibut were caught with 82 on brass, 81 on plastic, 82 on stainless steel and 27 on wood čibu $d$. In addition to Pacific halibut, we also caught seven individual fish as bycatch. There were two bycaught on brass čibu·d, three on plastic čibu $d$, one on stainless steel čibu $d$, and one that was entangled in the angler's fishing line and not actually hooked. Bycaught fish were of the species petrale sole (Eopsetta jordani), lingcod (Ophiodon elongatus), spiny dogfish (Squalus acanthias), and greenstripe rockfish (Sebastes elongatus).

We found strong evidence of differences in halibut catch rate by čibu $\cdot d$ type (ANOVA, $p<$ $0.001, \mathrm{~F}=10.6, \mathrm{df}=307)$. The observed differences in catch rates were due to significantly less catch of halibut on wood than on stainless steel, brass, or plastic čibu $\cdot d$ (Tukey HSD, p $<0.001$ for all comparisons to wood; Fig. 4). No evidence was found for differences in catch between the brass, stainless steel, and plastic čibu $\cdot d$.

\section{Comparison of rate of fish hooked and lost}

We found strong evidence of differences in rates of landing a fish once hooked by hook type (Fisher's Exact Test, $\mathrm{p}<0.001$ ). Anglers landed (brought aboard the boat) $62 \%$ of fish hooked on brass čibu $\cdot d, 60 \%$ on stainless steel, $53 \%$ on plastic and $19 \%$ on wooden čibu $d$. No evidence was found for statistical differences in whether or not a hooked fish was landed between the plastic, brass, and stainless steel čibu·d (Fisher's Exact Test, $p=0.66$ ).

\section{Angler surveys}

We conducted post-fishing interviews with 69 of the 77 volunteers. We found strong evidence that anglers preferred which type of čibu $\cdot d$ they fished (Fig. 4, Friedman test, $X^{2}=13.62, d f=3, p$ $=0.004)$. A post-hoc test revealed that the preference was driven by anglers having a significantly stronger preference for brass, stainless steel or plastic than for wood $(\mathrm{p}=0.020$ and $p=0.007$, respectively). No difference was found in angler preference for plastic, brass, or stainless steel čibu $\cdot d$.

\section{Phase 2}

During phase 2 of the study we compared fishing performance of brass čibu $d$ to a single $16 / 0$ circle and to paired $8 / 0$ circle hooks. Our choice of the brass čibu $d \mathrm{~d}$ was primarily to have 
295

296

297

298

299

300

301

302

303

304

305

306

307

308

309

310

311

312

313

314

315

316

317

318

319

320

321

322

323

324

325

326

327

328

329

330

331

332

333

continuity with our previous study (Scordino et al., 2017). Other factors that influenced are decision were that the brass čibu $\cdot d$ was easier to manufacture than the stainless steel čibu $\cdot d$ and it had similar performance and angler preference as the stainless steel and plastic čibu $\cdot d$.

In phase 2, anglers caught 346 fish composed of 205 Pacific halibut and 141 fish of bycatch species during phase 2 of the study (Table 1). A total of 1.4 halibut were caught on paired 8/0 circle hooks for every 1 caught on čibu'd and 1.2 halibut on a single 16/0 circle hook for every 1 caught on a čibu $\cdot d$. The halibut catch rate was not statistically different by hook type (ANOVA, $\mathrm{df}=2,102, p=0.49 ;$ Fig. 5 ).

There was strong evidence for differences in bycatch by hook type (ANOVA, $\mathrm{df}=2,102, \mathrm{p}<$ 0.0001 ; Fig. 5). The paired $8 / 0$ circle hooks had roughly ten times more bycatch than the čibu $d$, and the $16 / 0$ had roughly five times more bycatch than the čibu'd (Fig. 5). A Tukey HSD test revealed strong evidence for difference in bycatch on čibu $d$ and paired $8 / 0$ circle hooks $(p<$ $0.0001)$, a single $16 / 0$ circle hook and paired $8 / 0$ circle hooks $(p=0.0026)$, and suggestive evidence of difference in catch of bycatch on a čibu $\cdot d$ and a $16 / 0$ circle hook $(p=0.054)$.

Likewise, our analysis using the pooled data from all phase 2 sets showed strong evidence for differences in bycatch ratios (halibut caught per bycatch species caught) by hook type ( $\mathrm{X}^{2}=$ $31.43, \mathrm{df}=2, \mathrm{p}<0.001$ ). The bycatch ratio (halibut:bycatch) on the three hook types were $0.88: 1$ for paired 8/0 circles hooks, $1.6: 1$ for the single $16 / 0$ circle hook, and $6.3: 1$ for the brass čibu $d$. A post hoc pairwise comparison revealed evidence of differences in the observed bycatch ratios between paired $8 / 0$ circle hooks and the $16 / 0$ circle hook $(p=0.049)$ and strong evidence for differences in bycatch ratios for čibu $\cdot d$ and the paired $8 / 0$ circle hooks $(p=0.003)$ and the čibu $\cdot d$ and the single $16 / 0$ circle hook $(\mathrm{p}<0.001)$.

Significant differences in catch rates per set were found for all flatfish pooled and all roundfish pooled on different hook types (Table 1). None of the species of flatfish independently had significant differences in catch rates by hook type. The differences in catch of lingcod and spiny dogfish appear to have driven the significant differences in catch rates for round fish as both independently had strong evidence of significant differences in catch rate by hook type.

\section{Evaluating performance of improved čibu $\cdot d$ as compared to previous study}

The ratio of one halibut caught on our improved čibu $d$ to every 1.4 halibut caught on paired $8 / 0$ circle hooks in phase 2 of this study was significantly better ratio than our previous čibu $d$ design that had 1 halibut caught on čibu $d$ for every 2.9 caught on paired circle hooks (Fisher's Exact Test, $p=0.001$ ). The ratio of bycatch caught on cribu $\cdot d$ to paired $8 / 0$ circle hooks was not significantly different between the two studies (Fisher's Exact Test, p-value $=0.12$ ). 


\section{Discussion}

335

336 The objective of this study was to evaluate if design and manufacturing modifications to the

337 čibu $\cdot d$ tested in our previous study (Scordino et al., 2017) could improve halibut catch rates

338 while maintaining reductions of bycatch relative to contemporarily fished circle hooks. To

339 achieve this objective, we conducted a two-phase study. In phase 1 of the study, we evaluated čibu $d$ manufactured of four different materials that were thought to have different buoyancy and thus fish differently. We found that plastic, brass, and stainless steel čibu $\cdot d$ all caught halibut at a similar rate suggesting that the buoyancy and weight of the čibu $\cdot d$ did not affect its fishing performance for halibut. In phase 2 of the study, we compared the brass čibu $d$ to two contemporary hook designs commonly fished by recreational halibut anglers: a single $16 / 0$ circle hook and paired $8 / 0$ circle hooks. We found no statistical differences in the catch rate of halibut of the čibu $\cdot d$, the paired $8 / 0$ circle hooks, and the single $16 / 0$ circle hook. The improved brass čibu $\cdot d$ still drastically reduced bycatch; the čibu $\cdot d$ caught four times more halibut per bycaught fish than the single 16/0 circle hook and seven times more halibut per bycatch fish than the paired 8/0 circle hooks. Compared to our previous design (Scordino et al., 2017), the improved brass čibu $d$ used in this study had nearly a twofold better catch rate of halibut relative to concurrently fished paired $8 / 0$ circle hooks.

352

353

Our finding that the brass, stainless steel, and plastic čibu $\cdot d$ outperformed the wooden čibu $\cdot d$ during phase 1 of this study should not be viewed as a definitive finding that the materials make better čibu $\cdot d$. The wood čibu $\cdot d$ were the most difficult to make and as a result we had much more variability in their shape and barb position than we had in čibu $d d$ made with the other materials. It is quite likely that some of our wood čibu $d$ performed poorly due to their shape alone as some did not have the optimum shape we determined in our previous study (Scordino et al. 2017). We also found that some of our wood čibu $d$ either did not hold shape when fished due to saturating with water or were otherwise very weak resulting in an almost three fold reduction in catch retention as compared to the čibu $d$ made from other materials. The variability in the structural strength of our wood čibu $\cdot d$ was likely because we made wood čibu $d$ using both tension wood and compression wood not knowing until the study was under way that tension wood has less structural strength (Arima, 1975). In this study, we tried to mimic wooden hooks made by master builders who learned from their parents and grandparents who had previously mastered the craft. If our wooden čibu $\cdot d$ were made by master artisans as wood čibu $d$ were in the past, then it is likely that the catch rates of wooden čibu $\cdot d$ would have been more similar to the other materials. Likewise, it is quite possible that our metal replicates of Makah halibut hooks did not perform as well as metal čibu $\cdot d$ used in the past by tribal members who fished the hooks regularly and modified their hooks to optimize performance.

373

We do not know what makes the čibu $d$ selective for catching halibut. Stewart (1977) speculated that only flatfish, whose mouths are oriented perpendicular to the orientation of round-bodied fish, could successfully slide their mouth between the barb and the frame of the čibu $\cdot d$. Bycatch 
375 on čibu $d$ in this study may have occurred when the orientation of the čibu $d$ was shifted when

376 anglers bounced their weight along the bottom making it so roundfish could more easily pass

377 their mouth between the barb and frame of the čibu $\cdot d$. We encourage researchers to film halibut,

378 yelloweye rockfish, spiny dogfish, and lingcod in either the wild or in a controlled aquarium

379 setting to observe the mechanics of how each attacks a baited čibu $d$ to determine what attributes

380 of the čibu $\cdot d$ shape influences whether or not the fish is hooked. Understanding what attributes

381 reduce bycatch may allow modifications to the čibu $\cdot d$ design, or to the design of other hooks, to

382 further improve catch selectivity.

383

384

385

386

387

388

389

390

391

392

393

394

395

396

397

398

399

400

401

402

403

404

405

406

407

408

409

410

411

412

413

Although the objective of this study was to evaluate the fishing performance of čibu $\cdot d$, the study design also allowed us to compare the fishing performance of two hook configurations commonly used by recreational anglers. Many halibut anglers in Washington selectively use larger hooks to reduce bycatch of non-target species (Scordino et al., 2017). Our results showing a nearly twofold reduction in bycatch per set and twofold increase in halibut caught per bycatch caught on the single $16 / 0$ circle hook as compared to the paired $8 / 0$ circle hooks indicate that anglers using a larger circle hook have made the correct choice to reduce bycatch.

Bycatch in fisheries, even recreational fisheries, can be detrimental to the recovery of depleted fish stocks (Cooke \& Cowx, 2004; Hall \& Mainprize, 2005; Ihde et al., 2011). The results of this study demonstrate that hook selection significantly affects bycatch in recreational halibut fisheries. Recreational anglers can be educated on the benefits of selecting large $(>16 / 0)$ circle hooks to encourage their voluntary use to reduce bycatch during halibut fishing (Cooke et al., 2013). Likewise, resource managers can mandate the use of large circle hooks in management areas with bycatch concerns. Currently the čibu $\cdot d$ is not commercially produced and available to the public. Once the čibu $d$ is available to the public, voluntary use by anglers, or regulations that require its use, would have even more conservation benefit in recreational halibut fisheries than the use of large circle hooks.

\section{Conclusions}

In our previous study (Scordino et al., 2017), we found that čibu $\cdot d$ could potentially be used as a tool by managers to reduce bycatch in recreational halibut fisheries. The caveat to that conclusion was that recreational anglers would likely not voluntarily switch to using the čibu $\cdot d$ due to the observed significant reductions in halibut catch rates compared to contemporary hook designs (Arlinghaus, 2006). In this study we improved the design of the čibu $\cdot d$ and showed that if a čibu $\cdot d$ is properly designed and constructed that it has similar catch rates of halibut as commonly fished circle hooks while maintaining beneficial reductions of bycatch. After modification, the čibu $\cdot d$ is now a tool that recreational anglers and fisheries managers can use to reduce bycatch in recreational halibut fisheries while not sacrificing halibut fishing performance. We strongly encourage the commercial manufacture of čibu $d$ to allow the use of this selective

414 hook in recreational halibut fisheries. We encourage requiring the use of large hooks (16/0 or 
415 larger) in areas where bycatch is a concern in recreational halibut fisheries and for requiring the

416 use of čibu $d$ when they are commercially available.

\section{Acknowledgements}

418

419

We would like to thank the deckhands and captains of the Windsong particularly B. Maxson, D. Dawson, and M. Hunter. Makah Tribal member, J. Monette, played a critical role in research and development of the wood čibu·d used in this study. Thank you to the Makah Cultural and Research Center for input on making wood čibu $\cdot d$ and allowing us to examine historic samples. The manuscript was reviewed and edited by E. Allyn. Thank you to the Makah Tribal Council and the International Pacific Halibut Commission for supporting this study. We would also like

425 to thank the 119 volunteers that participated as anglers during the study. Views and opinions expressed in this paper are the authors and do not necessarily represent the Makah Tribe or the National Marine Fisheries Service.

428

429

430

431

432

433

434

435

436

437

438

439

440

441

442

443

444

445

446

447

448

449

450

451

452

453

454

455

456

\section{References}

Arima EY. 1975. Notes on the southern west coast (Nootka) natives: Environment and exploitative techniques of the P'a:chi:da?atH of Port San Juan. Available at the Makah Cultural and Research Center (accesssed 15 July 2017)

Arlinghaus R. 2006. On the apparently striking disconnect between motivation and satisfaction in recreational fishing: the case of catch orientation of German anglers. North American Journal of Fisheries Management 26:592-605. DOI: 10.1577/M04-220.1.

Bellquist L, Beyer S, Arrington M, Maeding J, Siddall A, Fischer P, Hyde J, Wegner NC. 2019. Effectiveness of descending devices to mitigate the effects of barotrauma among rockfishes (Sebastes spp.) in California recreational fisheries. Fisheries Research 215:44-52. DOI: 10.1016/j.fishres.2019.03.003.

Coleman FC, Figueira WF, Ueland JS, Crowder LB. 2004. The impact of United States recreational fisheries on marine fish populations. Science 305:1958-1960. DOI: 10.1126/science. 1100397.

Collins CC. 1996. Subsistence and survival: The Makah Indian Reservation, 1856-1933. The Pacific Northwest Quarterly 87:180-193.

Cooke SJ, Cowx IG. 2004. The role of recreational fishing in global fish crises. Bioscience 54:857-859. DOI: 10.1641/0006-3568(2004)054[0857:TRORFI]2.0.CO;2.

Cooke SJ, Suski CD, Arlinghaus R, Danylchuk AJ. 2013. Voluntary institutions and behaviours as alternatives to formal regulations in recreational fisheries management. Fish and Fisheries 14:439-457. DOI: 10.1111/j.1467-2979.2012.00477.x.

Figus E, Criddle KR. 2019. Comparing self-reported incidental catch among fishermen targeting Pacific halibut and a fishery independent survey. Marine Policy 100:371-381. DOI: 10.1016/j.marpol.2018.12.008.

Hall SJ, Mainprize BM. 2005. Managing by-catch and discards: How much progress are we making and how can we do better? Fish and Fisheries 6:134-155. DOI: 10.1111/j.14672979.2005.00183.x. 
457

458

459

460

461

462

463

464

465

466

467

468

469

470

471

472

473

474

475

476

477

478

479

480

481

482

483

484

485

486

487

488

489

490

491

492

493

494

495

496

497

Hannah RW, Parker SJ, Matteson KM. 2008. Escaping the surface: The effect of capture depth on submergence success of surface-released Pacific rockfish. North American Journal of Fisheries Management 28:694-700. DOI: 10.1577/M06-291.1.

Hannah RW, Rankin PS, Blume MTO. 2014. The divergent effect of capture depth and associated barotrauma on post-recompression survival of canary (Sebastes pinniger) and yelloweye rockfish (S. ruberrimus). Fisheries Research 157:106-112. DOI: 10.1016/j.fishres.2014.04.007.

Ihde TF, Wilberg MJ, Loewensteiner DA, Secor DH, Miller TJ. 2011. The increasing importance of marine recreational fishing in the US: Challenges for management. Fisheries Research 108:268-276. DOI: 10.1016/j.fishres.2010.12.016.

Kaimmer S. 2004. 1998 gear and bait experiments. International Pacific Halibut Commission Technical Report No. 48:1-36.

Lewison RL, Crowder LB, Read AJ, Freeman SA. 2004. Understanding impacts of fisheries bycatch on marine megafauna. Trends in Ecology and Evolution 19:598-604. DOI: 10.1016/j.tree.2004.09.004.

Malindine J. 2017. Northwest coast halibut hooks: An evolving tradition of form, function, and fishing. Human Ecology 45:53-65. DOI: 10.1007/s10745-016-9884-z.

McPhee DP, Leadbitter D, Skilleter GA. 2002. Swallowing the bait: Is recreational fishing in Australia ecologically sustainable? Pacific Conservation Biology 8:40-51. DOI: 10.1111/j.1467-8470.1994.tb00663.x.

Rankin PS, Hannah RW, Blume MTO, Miller-Morgan TJ, Heidel JR. 2017. Delayed effects of capture-induced barotrauma on physical condition and behavioral competency of recompressed yelloweye rockfish, Sebastes ruberrimus. Fisheries Research 186:258-268. DOI: 10.1016/j.fishres.2016.09.004.

Salmen-Hartley JU. 2018. Towards a historical ecology of halibut fishing on the northwest coast. M. Sci. Thesis, University of Victoria.

Scordino JJ, Petersen JR, Monette JL, Scordino J. 2017. Evaluation of the čibu $\cdot d$, traditional halibut hook of the Makah Tribe, for reducing catch of non-target species in recreational Pacific halibut fisheries. Fisheries Research 185:17-25. DOI: 10.1016/j.fishres.2016.09.030.

Stevens JD, Bonfil R, Dulvy NK, Walker PA. 2000. The effects of fishing on sharks, rays, and chimaeras (chondrichthyans), and the implications for marine ecosystems. ICES Journal of Marine Science 57:476-494. DOI: 10.1006/jmsc.2000.0724.

Stewart H. 1977. Indian fishing: Early methods on the Northwest coast. Seattle, Washington: University of Washington Press.

Swan JG. 1870. The Indians of Cape Flattery, at the entrance to the Strait of Fuca, Washington Territory. Smithsonian Contributions to Knowledge 16:ix+108pp.

Trumble RJ. 1996. Management of Alaskan longline fisheries to reduce halibut bycatch mortality. In: Solving bycatch: Considerations for today and tomorrow. Fairbanks, Alaska: Alaska Sea Grant, 183-192. 
Figure $\mathbf{1}$ (on next page)

Side by side representation of the handmade čibu.d fished in the Scordino et al. (2017) study (A) and the improved čibu.d design used in this study (B).

(1) Changes to leader attachment method. (2) Standardization of the shape of the cribu.d frame and position of the barb $36 \mathrm{~mm}$ above the bottom of the čibu.d frame. (3) Changes in the material used for the barb. (4) Changes to methods to attach the barb for the improved čibu.d. 


\section{Figure 2}

Photograph of representative čibu $d$ used in phase 1 of this study and circle hooks used in phase 2 of this study.

(a) Wood čibu $d$ made of western hemlock branch with a bone barb made from elk femur and wraps of split Sitka spruce root. (b) Plastic čibu dd made of 33\% glass filled nylon with a 316 stainless steel barb. (c) Brass čibu d d made of 360 half-hard tempered brass with a 316 stainless steel barb. This hook was used in phase 1 and 2 of this study. (d) Stainless steel čibu $\cdot d$ made of 316 stainless steel with a 316 stainless steel barb. (e) Paired 8/0 circle hooks. (f) $16 / 0$ circle hook. 


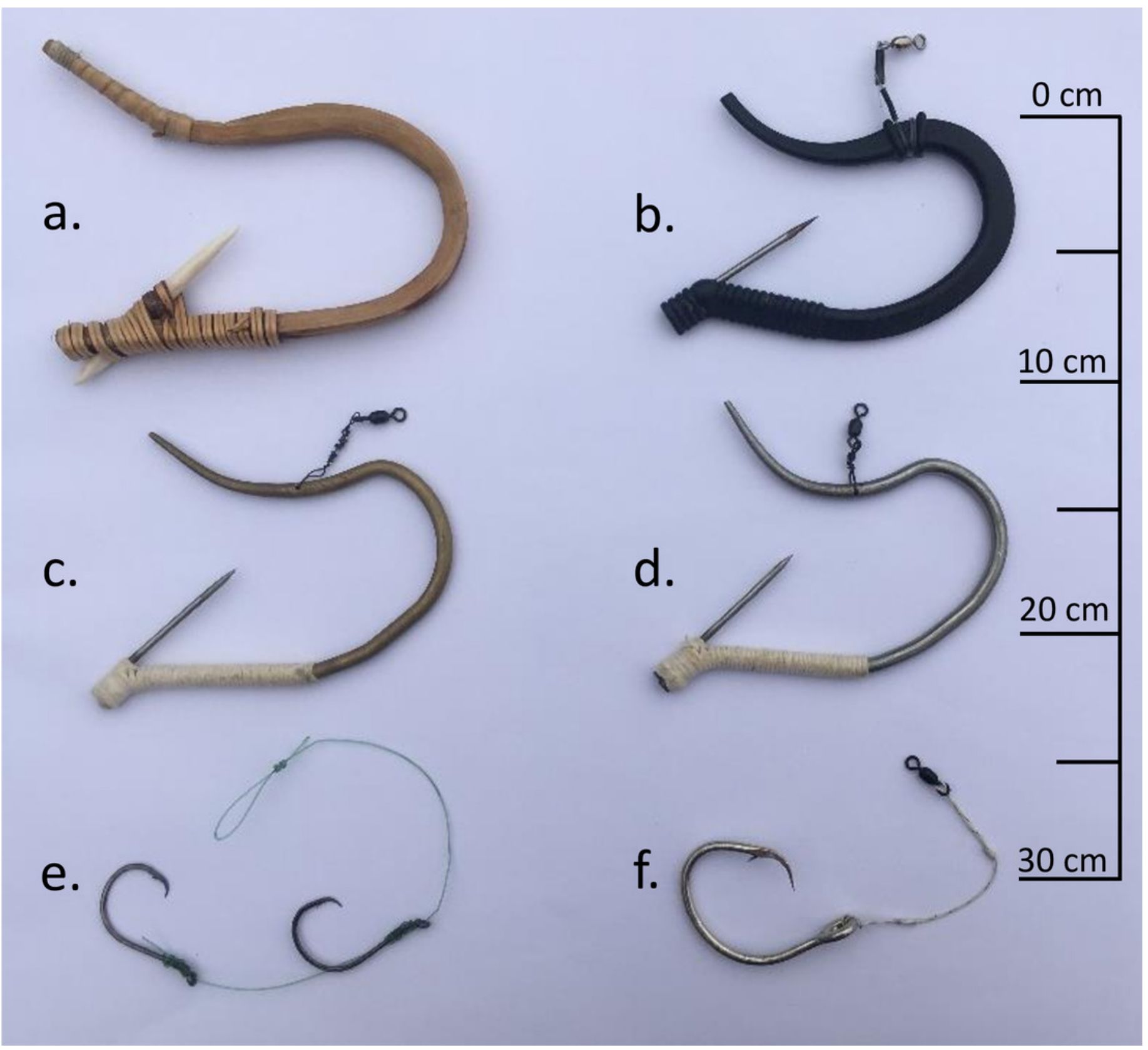




\section{Figure 3}

Map showing sites fished during the two phases of the study.

Fishing sites are shown by symbol for the years they were fished: circles represents sites fished in 2017 only, squares were fished in 2018 only, and triangles were sites fished in both years. The star shows the location of the Port of Neah Bay from which research was conducted.

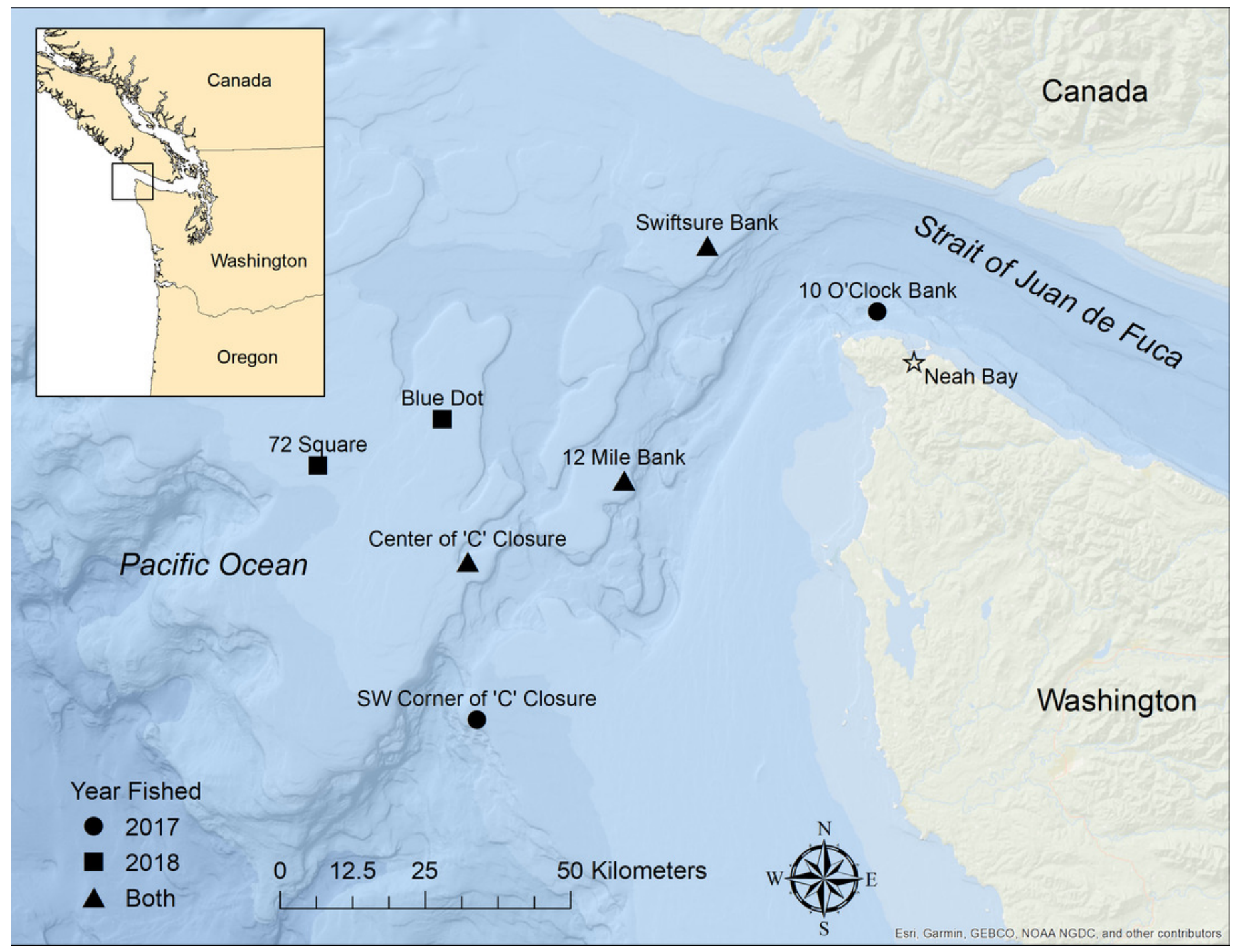


Figure 4

Halibut caught per set by čibu'd made of each of the four materials tested.

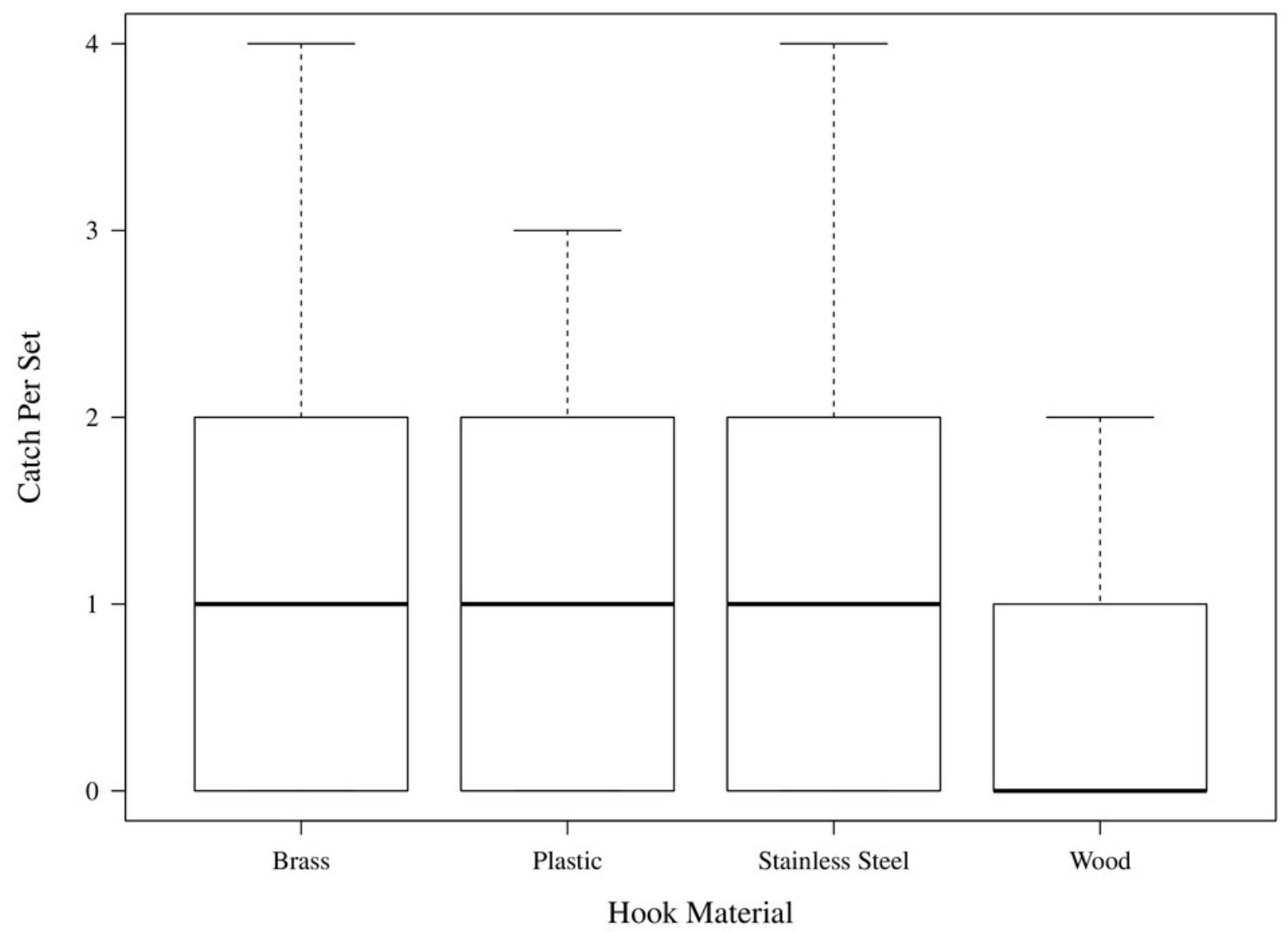


Figure 5

Catch of halibut and bycatch per set for čibu $\cdot d$ manufactured from brass, plastic, stainless steel, and wood.

$(*)$ In this study we defined all catch of species other than Pacific halibut as bycatch. 


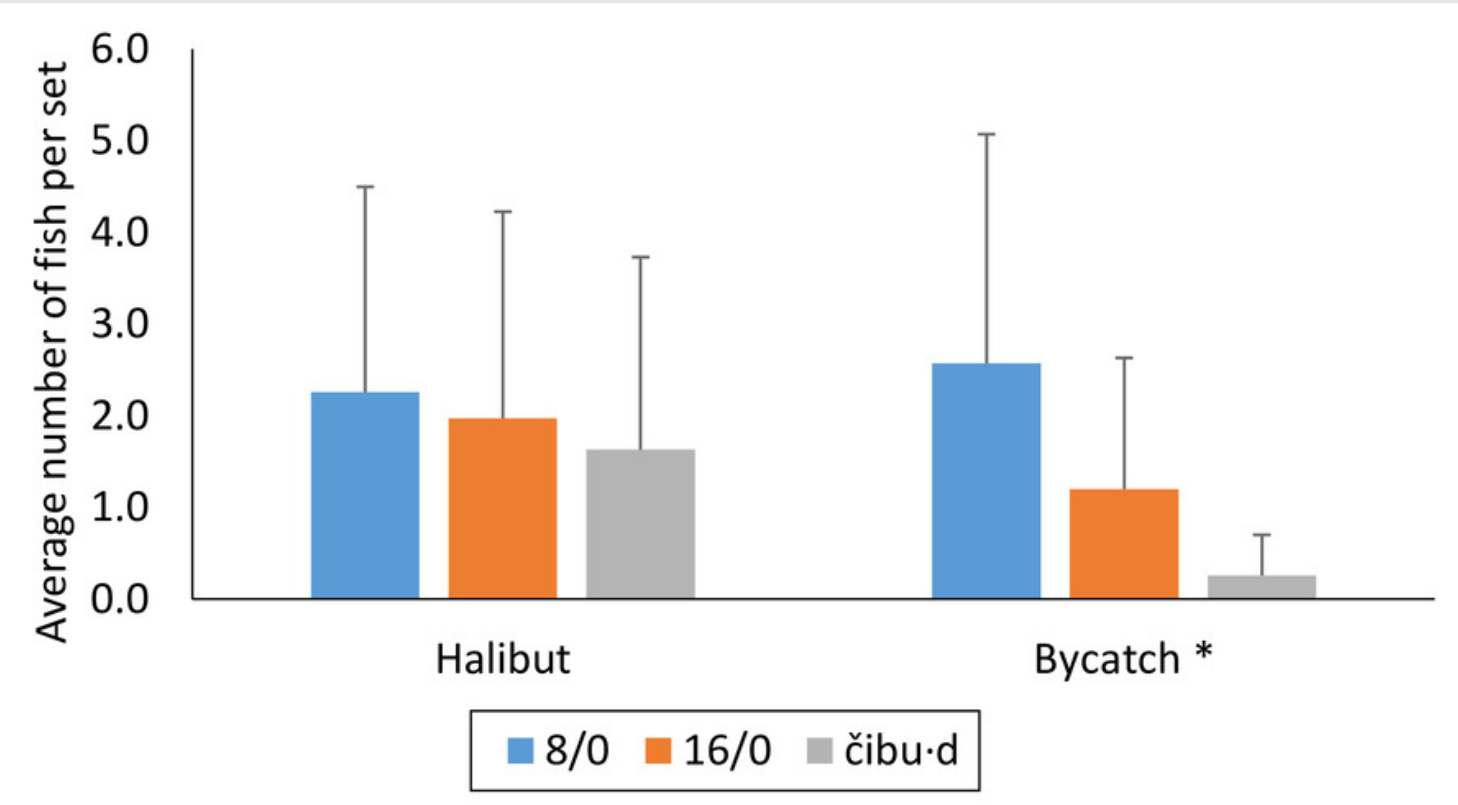




\section{Table $\mathbf{1}$ (on next page)}

Average catch per set by species and species groups by hook type during phase 2 of the study.

Species or species groups with significant differences $(p<0.05)$ in catch rate by hook type are marked with an asterisk. 


\begin{tabular}{|c|c|c|c|}
\hline \multirow[b]{2}{*}{ Species } & \multicolumn{3}{|c|}{ Average catch per set } \\
\hline & Paired $8 / 0$ circle hooks & 16/0 circle hook & čibu.d \\
\hline Pacific halibut & 2.257 & 1.971 & 1.629 \\
\hline Bycatch species pooled $*$ & 2.571 & 1.200 & 0.257 \\
\hline Non-halibut flatfishes pooled * & 0.514 & 0.257 & 0.086 \\
\hline Petrale sole & 0.229 & 0.114 & - \\
\hline Arrowtooth flounder & 0.286 & 0.143 & 0.086 \\
\hline Roundfishes pooled $*$ & 2.057 & 0.943 & 0.171 \\
\hline Rockfishes pooled & 0.457 & 0.200 & 0.086 \\
\hline Canary rockfish & 0.057 & 0.057 & - \\
\hline Redstripe rockfish & 0.029 & 0.029 & - \\
\hline Rosethorn rockfish & 0.029 & - & - \\
\hline Tiger rockfish & 0.029 & - & - \\
\hline Yelloweye rockfish & 0.286 & 0.114 & 0.086 \\
\hline Yellowtail rockfish & 0.029 & - & - \\
\hline Pacific spiny dogfish * & 0.743 & 0.571 & 0.029 \\
\hline Lingcod * & 0.571 & - & 0.057 \\
\hline Sablefish & 0.257 & 0.171 & - \\
\hline Coho salmon & 0.029 & - & - \\
\hline
\end{tabular}

1 